\section{Modification of Plant Arrangement Suppresses White Mold of Snap Beans}

\author{
Ed Peachey ${ }^{1}$ \\ Department of Horticulture, Oregon State University, Corvallis, OR 97331
}

Robin L. Ludy

Oregon Department of Agriculture, Agricultural Building, 635 Capitol St. NE, Salem, OR 97310

Mary L. Powelson

Emeritus, Department of Botany and Plant Pathology, Oregon State University, Corvallis, OR 97331

Daniel M. McGrath

Oregon State University Extension Service, Linn County Office, 104 Fourth St SW, Albany, OR 97312

Additional index words. cultural control, disease suppression, Phaseolus vulgaris

\begin{abstract}
Field studies were conducted in 1999 and 2001 in western Oregon to determine the effect of between-row spacing on severity of white mold (Sclerotinia sclerotiorum) in snap beans. Planting density was held constant at 445,000 plants ha ${ }^{-1}$ and between-row spacing ranged from 19 to $150 \mathrm{~cm}$. Disease severity and pod rot were greatest in both years of study at the 19-cm between-row spacing and declined linearly as between-row widths increased. Severity of disease in 1999 was $24 \%, 41 \%$, and $88 \%$ lower at the 38 -, $75-$, and $150-\mathrm{cm}$ between-row spacings, respectively, than at the 19-cm row spacing. In 2001 , disease severity was $11 \%, 25 \%, 34 \%$, and $51 \%$ less at the between-row widths of 38 , 75,114 , and $150 \mathrm{~cm}$, respectively, than at the $19-\mathrm{cm}$ row spacing. Incidence of pod rot declined by $0.24 \%$ and $0.64 \%$ for each $10-\mathrm{cm}$ increase in between-row width in 1999 and 2001, respectively. The fungicide vinclozolin effectively suppressed pod rot in both years at all between-row spacings. Pod yield was not influenced by between-row spacings of 19 to $114 \mathrm{~cm}$, but yield was significantly lower at the between-row spacings of $150 \mathrm{~cm}$. Increasing the between-row width of snap bean rows may be an effective disease management tactic to suppress white mold when fungicides are not applied or if efficacious fungicides are not available.
\end{abstract}

White mold, incited by Sclerotinia sclerotiorum (Lib.) de Bary, reduces yield and quality of snap beans if environmental conditions are favorable for disease development. The disease is favored by cool, wet weather during bloom. Under long periods of leaf wetness, ascospores of $S$. sclerotiorum germinate and infect senescing petals and other senescent tissues (Abawi and Grogan, 1979). Robust plant growth and dense canopies support longer periods of leaf wetness, which favors development of white mold (Deshpande et al., 1995). One application of the fungicide vinclozolin (Ronilan, Cerexagri, King of Prussia, Pa.) has provided exceptional control of white mold in commercial snap bean plantings over the last 18 years. Because of human health concerns, vinclozolin will not be registered for use in 2006 (Shah et al., 2002). Thiophanate-methyl (Topsin, BASF, Triangle Park, N.C.), iprodione (Rovral, Bayer Crop Science LP, Triangle Park, N.C.), and boscalid (Endura,

Received for publication 10 Mar. 2006. Accepted for publication 5 Apr. 2006.

${ }^{1}$ To whom correspondence should be addressed; e-mail peacheye@hort.oregonstate.edu widths of $76 \mathrm{~cm}$ than at 25 to $38 \mathrm{~cm}$ (Grau and Radke, 1984). Both plant density and row spacing were altered in a study on Great Northern dry beans (Phaseleous vulgaris). White mold incidence declined $10 \%$ as the between-row spacing increased from 16 to $76 \mathrm{~cm}$ and as plant populations decreased from 400,000 to 100,000 plants ha ${ }^{-1}$ (Kerr et al., 1992). White mold decreased in both short bush and upright dry bean cultivars as the between-row spacing was decreased from 80 to $30 \mathrm{~cm}$ (Park, 1993). In contrast, Saindon et al. $(1993,1995)$ concluded that both upright and viney dry bean cultivars can be grown in narrow rows without greatly increasing the risk of a white mold outbreak. The effect of modified planting arrangement on yield of snap beans has been reported in several studies (Mack and Varseveld, 1982; Wahab et al., 1986), but the effect of wider between-row spacings on white mold in snap beans at an optimum plant density is unknown.

In 1987, the majority of snap bean plantings in western Oregon had a between-row spacing of $90 \mathrm{~cm}$ and a final plant stand of 296,000 to 432,000 plants ha $^{-1}$. By 1996, over $40 \%$ of the growers had purchased or adapted new planting equipment and changed their between-row spacing to $76 \mathrm{~cm}$ or less while maintaining high plant populations. The majority of growers now have a between-row spacing of $60 \mathrm{~cm}$ with plant populations at or above 445,000 ha ${ }^{-1}$ (Defransico, 2005). The increase in plant population and reduction in the distance between rows in this production region is likely the result of superior efficacy of the fungicide vinclozolin and economic pressures to improve yield. Adjusting row spacings in response to potential white mold outbreaks may reduce the risk of managing white mold with alternative fungicides. The objective of this study was to determine the effect of between-row spacing and vinclozolin on white mold and crop yield in snap beans grown at an optimum plant population.

\section{Materials and Methods}

The experiment was conducted during the 1999 and 2001 growing seasons at the Oregon State University Horticulture Farm near Corvallis in a field naturally infested with sclerotia of $S$. sclerotiorum. The experimental design was a randomized split plot with 6 blocks. Treatments were arranged in a $2 \times 4$ factorial design with fungicide (vinclozolin or no vinclozolin) as the subplot and between-row spacings $(19,38,75$, or $150 \mathrm{~cm})$ as the main plots. In 2001, an additional row spacing of $114 \mathrm{~cm}$ was included. A seeding rate of 445,000 seeds ha $^{-1}$ was kept constant for all treatments. This seeding rate has been shown to maximize yield potential of varieties commonly grown in the region (Mack and Varseveld, 1982; Mansour and Hemphill, 2002). Each plot was separated from neighboring plots by at least $3 \mathrm{~m}$ of snap beans planted at the between-row spacing of $75 \mathrm{~cm}$.

Fertilizer (NPK analysis of 12-29-10) was banded $5 \mathrm{~cm}$ deep and $5 \mathrm{~cm}$ to the side 
Table 1. Mixed-effect analysis of variance for effect of year, row spacing, and vinclozolin on plant population, white mold, and crop yield in snap beans.

\begin{tabular}{|c|c|c|c|c|c|c|c|c|c|}
\hline \multirow[b]{2}{*}{ Effect } & \multicolumn{2}{|c|}{ Degrees of freedom } & \multirow{2}{*}{$\frac{\text { Plant density at harvest }}{\text { F-value }^{\mathrm{a}}}$} & \multicolumn{3}{|c|}{ White mold ratings } & \multicolumn{3}{|c|}{ Crop yield } \\
\hline & Number & Density & & Incidence & Severity & $\overline{\text { Pod rot }}$ & Biomass & Pod weight & $\overline{\text { Grade }}$ \\
\hline$\overline{\text { Year }}$ & 1 & 95 & $5.4^{y}$ & $20.1^{x}$ & $22.0^{x}$ & $53.0^{x}$ & 0.9 & $6.3^{x}$ & $58.0^{\mathrm{x}}$ \\
\hline Year $\times$ spacing & 7 & 95 & $3.8^{\mathrm{y}}$ & $8.9^{\mathrm{x}}$ & $6.4^{x}$ & $38.0^{\mathrm{x}}$ & $7.2^{\mathrm{x}}$ & $4.6^{\mathrm{x}}$ & $1.2^{\mathrm{ns}}$ \\
\hline Year $\times$ vinclozolin & 2 & 95 & $0.1^{\mathrm{ns}}$ & $85.0^{\mathrm{x}}$ & $94.1^{\mathrm{x}}$ & $85.3^{x}$ & $18.7^{x}$ & $9.2^{\mathrm{x}}$ & $9.2^{\mathrm{y}}$ \\
\hline $\begin{array}{l}\text { Year } \times \text { spacing } \times \text { vinclozolin } \\
1999\end{array}$ & 7 & 95 & $0.8^{\mathrm{ns}}$ & $1.5^{\mathrm{ns}}$ & $1.6^{\mathrm{ns}}$ & $2.8^{\mathrm{x}}$ & $3.0^{\mathrm{z}}$ & $2.6^{z}$ & $2.1^{\mathrm{z}}$ \\
\hline Spacing & 3 & 15 & $0.4^{\mathrm{ns}}$ & $15.0^{\mathrm{x}}$ & $8.0^{y}$ & $4.6^{x}$ & $13.0^{\mathrm{x}}$ & $13.1^{\mathrm{x}}$ & $1.0^{\mathrm{ns}}$ \\
\hline Vinclozolin & 1 & 20 & $0.1^{\mathrm{ns}}$ & $8.0^{\mathrm{x}}$ & $10.1^{\mathrm{y}}$ & $10.0^{\mathrm{x}}$ & $12.0^{\mathrm{x}}$ & $13.3^{x}$ & $0.1^{\mathrm{ns}}$ \\
\hline Spacing $\times$ vinclozolin & 3 & 20 & $1.1^{\mathrm{ns}}$ & $2.1^{\mathrm{ns}}$ & $2.1^{\mathrm{ns}}$ & $4.9^{\mathrm{y}}$ & $9.4^{\mathrm{x}}$ & $8.0^{\mathrm{x}}$ & $1.5^{\mathrm{ns}}$ \\
\hline 2001 & & & & & & & & & \\
\hline Spacing & 4 & 19 & $3.0^{\mathrm{y}}$ & $8.0^{\mathrm{y}}$ & $8.7^{x}$ & $4.1^{\mathrm{y}}$ & $13.4^{\mathrm{x}}$ & $7.8^{\mathrm{x}}$ & $1.9^{\mathrm{ns}}$ \\
\hline Vinclozolin & 1 & 22 & $0.2^{\mathrm{ns}}$ & $167.0^{\mathrm{x}}$ & $202.3^{x}$ & $146.0^{x}$ & $24.2^{y}$ & $7.6^{y}$ & $8.3^{y}$ \\
\hline Spacing $\times$ vinclozolin & 4 & 22 & $1.0^{\mathrm{ns}}$ & $0.7^{\mathrm{ns}}$ & $1.0^{\mathrm{ns}}$ & $3.5^{\mathrm{x}}$ & $2.6^{\mathrm{z}}$ & $2.2^{\mathrm{z}}$ & $0.8^{\mathrm{ns}}$ \\
\hline
\end{tabular}

ns,z,y,x Nonsignificant, $P \leq 0.10,0.05$, and 0.01 , respectively.
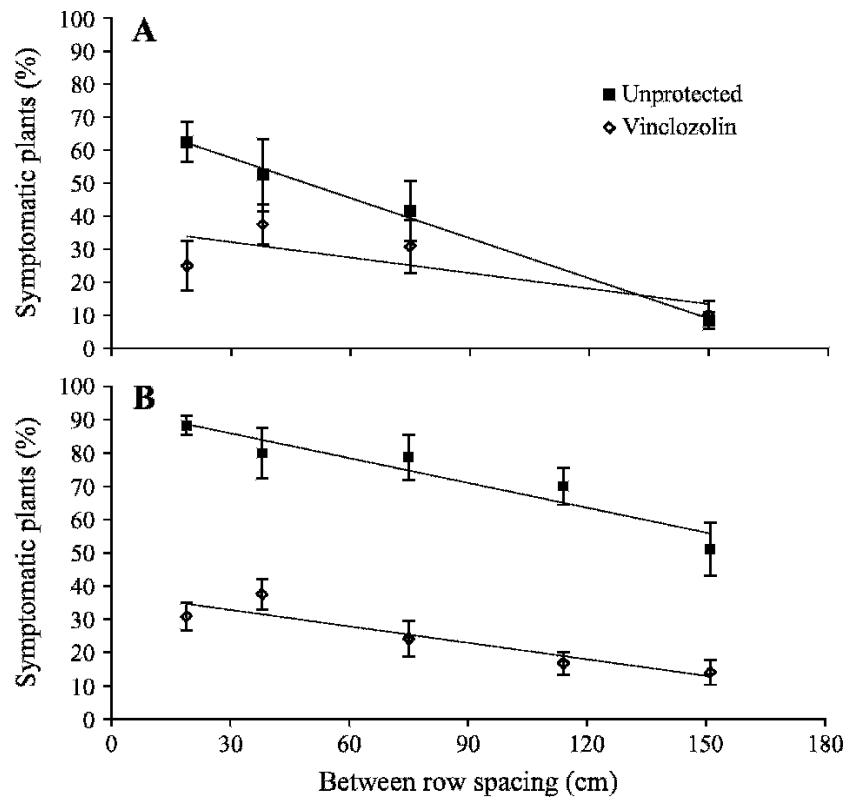

\begin{tabular}{|c|c|c|c|c|c|c|c|c|}
\hline \multirow[t]{2}{*}{ Year } & \multirow[t]{2}{*}{ Fungicide } & \multirow[t]{2}{*}{$\mathrm{F}$} & \multirow[t]{2}{*}{$\mathrm{Pr}>\mathrm{F}$} & \multirow[t]{2}{*}{$r^{2}$} & \multicolumn{2}{|r|}{$\alpha$} & \multicolumn{2}{|r|}{$\beta$} \\
\hline & & & & & Par & $\mathrm{CI}_{95}$ & Par & $\mathrm{CI}_{95}$ \\
\hline 1999 & Unprotected & 29.0 & $<0.0001$ & 0.57 & -0.40 & $-0.55 /-0.25$ & 70.0 & $56.3 / 83.1$ \\
\hline 1999 & Vinclozolin & 5.2 & 0.0326 & 0.19 & -0.15 & $-0.29 /-0.01$ & 36.8 & $24.5 / 49.1$ \\
\hline 2001 & Unprotected & 14.8 & 0.0006 & 0.35 & -0.27 & $-0.42 /-0.12$ & 95.0 & $81.0 / 109.1$ \\
\hline 2001 & Vinclozolin & 11.9 & 0.0018 & 0.30 & -0.17 & $-0.27 /-0.07$ & 38.7 & $29.4 / 48.1$ \\
\hline
\end{tabular}

Fig. 1. Effect of between-row spacing and vinclozolin on incidence of white mold in snap beans in 1999 (A) and 2001 (B) ( \pm standard error, $\mathrm{N}=6$ ). Regression statistics and parameter estimates are provided below for the linear models shown in the graphs (symptomatic plants $=\alpha[$ spacing $]+\beta$ ).

of each row at a rate of $380 \mathrm{~kg} \cdot \mathrm{ha}$ before planting in early July of each year. The semiupright, susceptible snap bean (Phaseolus vulgaris L var. OR91-G) was seeded with a belt push planter next to the fertilizer rows. Plots were sown at the end of the commercial planting season (7 and 5 July in 1999 and 2001, respectively) so that the blossom period would occur in late summer when conditions are generally conducive to white mold development. The herbicides EPTC (3.9 $\mathrm{kg}$ ai ha $\left.{ }^{-1}\right)$ and trifluralin $\left(0.6 \mathrm{~kg}\right.$ ai ha $\left.{ }^{-1}\right)$ were preplant-incorporated and metolachlor (1.7 kg ai ha ${ }^{-1}$ ) applied $1 \mathrm{~d}$ after planting. Plots were kept weed-free by regular hoeing. Plots were $7.5 \mathrm{~m}$ long and the number of rows per plot was $16,8,4$, or 2 and $16,8,4,3$, or 2 in 1999 and 2001, respectively, which corre- sponded to between-row spacings of 19,38 , 75 , or $150 \mathrm{~cm}$ and $19,38,75,114$, or $150 \mathrm{~cm}$, respectively. In 2001, plots were split in half, and additional nitrogen (urea at $60 \mathrm{~kg} \mathrm{~N} \mathrm{ha}^{-1}$ ) was banded between rows to encourage plant growth. The additional nitrogen had no significant effect on the variables reported, and data from the nitrogen subplots were pooled for analysis. Plots were irrigated weekly with approximately $2.5 \mathrm{~cm}$ of water. Beginning after first bloom, plots also were irrigated for $30 \mathrm{~min}$ in the early evening every other day to create conditions favorable for infection.

The fungicide vinclozolin was applied once in 1999 (24 Aug.) and twice in 2001 (16 and 25 Aug.) when approximately $50 \%$ of the blossoms were open. Vinclozolin was applied twice in 2001 because of vigorous plant growth and weather that was more conducive to disease development than in 1999. Vinclozolin was applied at $0.56 \mathrm{~kg}$ ai ha $\mathrm{ha}^{-1}$ in $3751 \mathrm{ha}^{-1}$ of water with a backpack $\mathrm{CO}_{2}$ sprayer with $80^{\circ}$ flat fan nozzles at 40 PSI.

Plots were harvested when random samples of pods were approximately $50 \%$ grade 1 (sieve size 1-4) on 7 and 10 Sept. in 1999 and 2001, respectively. Snap bean plants were pulled from an area equivalent to $2.5 \times 0.75$ $\mathrm{m}$, counted for stand establishment estimates, and weighed for biomass. All pods greater than $8 \mathrm{~cm}$ in length were stripped from the plants and weighed and graded with a Chisolm-ryder modified bean grader to ensure that results were not confounded by differences in maturity among treatments. Twenty plants and 200 pods were assessed for symptoms of white mold. The incidence of symptomatic plants and pods and severity of plant infection were recorded for each plot. White mold severity was rated on a scale of 0 to 5 in which $0=$ no mold, 1 = single branch infected, $2=2$ branches infected, $3=50 \%$ of branches infected, $4=$ more than $50 \%$ of the branches infected, and $5=$ plant dead.

Statistical analysis (analysis of variance) was performed using PROC MIXED procedures in SAS version 8.2 (SAS Institute, Cary, N.C.) with block, block by spacing, block by fungicide, and block by spacing by fungicide as random variables. Disease incidence and severity data were square root transformed to increase the homogeneity of variance among treatments. Because statistically significant interactions between year, fungicide treatment, and row spacing were noted for several variables, data are presented separately for each year. Dependent variables of disease incidence, disease severity, and pod rot were regressed against between-row spacing with PROC GLM (SAS Institute, Cary, NC, 2000) and 95\% confidence intervals $\left(\mathrm{CI}_{95}\right)$ calculated for the parameter estimates of the linear model.

\section{Results}

Environmental conditions were conducive for disease development in both years of the experiment, but disease was more severe in 2001 than in 1999 (Table 1, Figs. 1-3). 

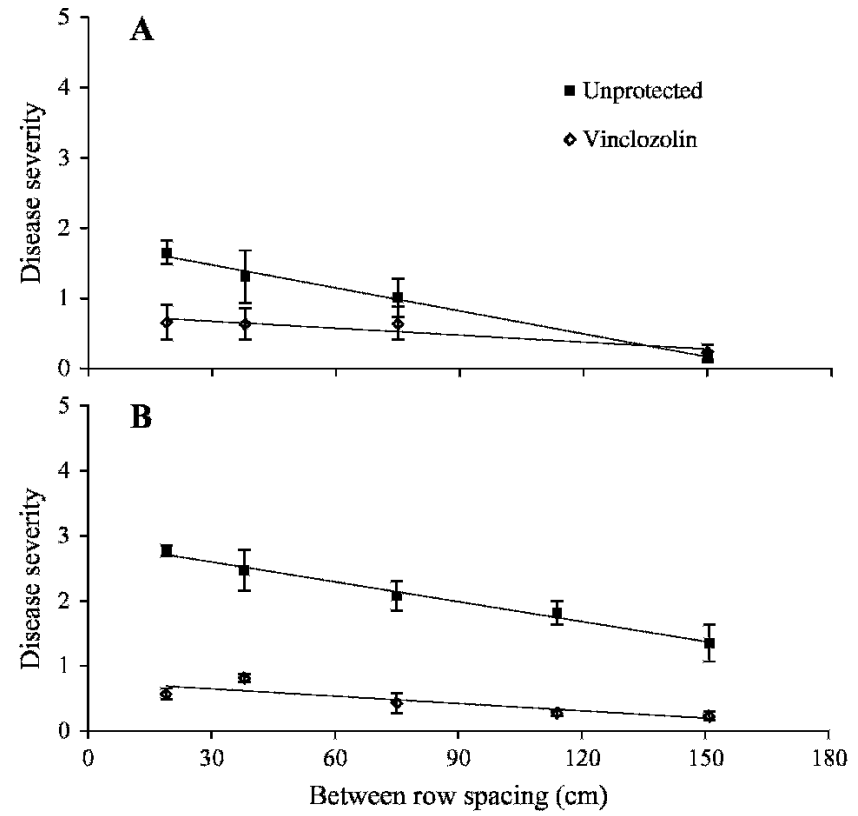

\begin{tabular}{|c|c|c|c|c|c|c|c|c|}
\hline \multirow[t]{2}{*}{ Year } & \multirow[t]{2}{*}{ Fungicide } & \multirow[t]{2}{*}{$\mathrm{F}$} & \multirow[t]{2}{*}{$\operatorname{Pr}>F$} & \multirow[t]{2}{*}{$r^{2}$} & \multicolumn{2}{|r|}{$\alpha$} & \multicolumn{2}{|r|}{$\beta$} \\
\hline & & & & & Par & $\mathrm{CI}_{95}$ & Par & $\mathrm{CI}_{95}$ \\
\hline 1999 & Unprotected & 21.4 & 0.0003 & 0.49 & -0.011 & $-0.016 /-0.006$ & 1.8 & $1.4 / 2.2$ \\
\hline 1999 & Vinclozolin & 2.7 & 0.1181 & 0.11 & -0.003 & $-0.007 / 0.001$ & 0.8 & $0.4 / 1.1$ \\
\hline 2001 & Unprotected & 17.2 & 0.0003 & 0.38 & -0.011 & $-0.017 /-0.006$ & 3.0 & $2.4 / 3.5$ \\
\hline 2001 & Vinclozolin & 11.0 & 0.0025 & 0.28 & -0.004 & $-0.006 /-0.001$ & 0.8 & $0.6 / 1.0$ \\
\hline
\end{tabular}

Fig. 2. Effect of between-row spacing and vinclozolin on severity of white mold in snap beans in 1999 (A) and $2001($ B $)( \pm$ standard error, $N=6)$. Severity was calculated as $(\mathrm{N} 1 \times 1+\mathrm{N} 2 \times 2+\mathrm{N} 3 \times 3+\mathrm{N} 4 \times 4+$ $\mathrm{N} 5 \times 5) / \mathrm{N}$, in which $\mathrm{N}=20, \mathrm{~N} 1=$ number of plants with one infected branch, $\mathrm{N} 2=$ number of infected plants with 2 or more infected branches, N3 = number of plants with $50 \%$ of branches infected plus at least one pod infection, $\mathrm{N} 4=$ number of plants with more than $50 \%$ of branches infected plus multiple pod infections, and N5 = number of dead plants. Regression statistics and parameter estimates are provided below for the linear models shown in the graphs (disease severity $=\alpha[\operatorname{spacing}]+\beta$ )

The incidence of plant infection, when averaged across row spacings without fungicide, was $41\left(\mathrm{CI}_{95} 31-52\right)$ and $72 \%\left(\mathrm{CI}_{95} 62-81\right)$ in 1999 and 2001, respectively. Disease severity averaged $1.1\left(\mathrm{CI}_{95} 0.7-1.4\right)$ and $2.0\left(\mathrm{CI}_{95}\right.$ 1.7-2.4) in 1999 and 2001, respectively. Pod rot in untreated plots was $2.0 \%\left(\mathrm{CI}_{95} 0.4 \%\right.$ to $3.5 \%)$ in 1999 and $7.9 \%(6.4 \%$ to $9.3 \%)$ in 2001. Pods were larger in 2001 (51\% grade 1) than in 1999 (61\% grade 1$)$.

Between-row spacing had a significant effect on the disease. As the distance between rows increased, the incidence and severity of plant infection decreased (Table 1, Figs. 12). In 1991, linear regression indicated that the incidence of symptomatic plants decreased by $4 \%\left(\mathrm{CI}_{95} 2.5 \%\right.$ to $\left.5.5 \%\right)$ for each $10-\mathrm{cm}$ increase in between-row spacing (Fig. 1). In 2001, the incidence of symptomatic plants decreased $3.1 \%\left(\mathrm{CI}_{95} 1.7 \%\right.$ to $4.5 \%$ ) for each $10-\mathrm{cm}$ increase in betweenrow spacing. Disease severity decreased linearly from $1.7 \%$ at the $19 \mathrm{~cm}$ between-row spacing to $0.2 \%$ at the $150-\mathrm{cm}$ spacing in 1999 , and from $2.8 \%$ at the $19-\mathrm{cm}$ spacing to $1.4 \%$ at the $150-\mathrm{cm}$ row spacings in 2001 (Fig. 2). Similarly, the incidence of pod rot decreased by $0.24 \%\left(\mathrm{CI}_{95} 0.12 \%\right.$ to $\left.0.36 \%\right)$ and $0.64 \%\left(\mathrm{CI}_{95} 0.32 \%\right.$ to $\left.0.96 \%\right)$ for each $10-\mathrm{cm}$ increase of between-row spacing in 1999 and 2001, respectively (Fig. 3).

The fungicide vinclozolin significantly reduced disease at all row spacings, but also obscured the impact of narrow row spacings on disease. Linear regression indicated a $1.5 \%$ decrease $\left(\mathrm{CI}_{95} 0.1 \%\right.$ to $\left.2.9 \%\right)$ in the incidence of symptomatic plants for each $10-\mathrm{cm}$ increase in between-row spacing in 1999 (Fig. 1). However, the linear model explained less than $20 \%$ of the variability associated with row spacing because of the low incidence of symptomatic plants at the $19-\mathrm{cm}$ between-row spacing. Nonlinear regression did not improve model precision. The incidence of symptomatic plants decreased by $1.7 \%\left(\mathrm{CI}_{95} 0.7 \%\right.$ to $\left.2.7 \%\right)$ for each $10-\mathrm{cm}$ increase in 2001 (Fig. 1). There was no difference in disease severity among the four row spacings in 1999, but disease severity declined by $0.04 \%$ for each $10-\mathrm{cm}$ increase in between-row spacing in 2001 (Fig. 2). There was no difference in the incidence of pod rot among row spacing treatments when vinclozolin was applied (Fig. 3).

The effect of row spacing and vinclozolin on plant biomass and pod yield was not consistent in the 2 years (Tables 1 and 2).
Whereas there was no difference in plant biomass in the 2 years of the study (Table 1 ), yield was greater in 2001 than 1999 and was closely correlated with aerial biomass $(\mathrm{R}=$ 0.94; $P<0.0001)$. Pod grade averaged 46 and $61 \%$ grade 1 pods in 2001 and 1999 , respectively. A lower grade indicates accelerated maturity, and the later harvest in 2001 (3 d) may have caused yields to be slightly greater in 2001 than 1999.

Pod yields were the lowest at the $150-\mathrm{cm}$ row spacing whether vinclozolin was applied, but were highest at the $38-\mathrm{cm}$ spacing in 1999 and at the $75-\mathrm{cm}$ spacing in 2001 in unprotected plots. When vinclozolin was applied in 1999, yield was highest in plots with a between-row spacing of $19 \mathrm{~cm}(27.2$ MT ha ${ }^{-1}$ ), an increase of 5.8 and 7.1 MT ha over the yield at the 38- and 75-cm betweenrow spacings, respectively. There was no difference in yield in the vinclozolin treatments in 2001 for between-row spacings of 19 to $114 \mathrm{~cm}$. The application of vinclozolin may have accelerated snap bean maturity in 2001; the percentage of grade 1 snap bean pods decreased from $51 \%$ to $40 \%$ when vinclozolin was applied.

\section{Discussion}

An increase in between-row spacing reduced white mold in snap beans in 2 years at a constant planting density. However, final plant stand at harvest was not consistent among between-row treatments in 2001 . Plant density at harvest was 433,000 plants $\mathrm{ha}^{-1}$ at the $38-\mathrm{cm}$ between-row spacing and 304,000 at the $150-\mathrm{cm}$ spacing, an average difference of $25 \%$ that was probably incited by increased competition between plants at the wider row spacings (Table 2). It is unclear whether the stand reductions incited by wider between-row spacings influenced white mold development, but the correlation between plant population at harvest and mold incidence in plots without fungicide was very poor $(\mathrm{R}<0.1)$.

The effect of between-row spacing on white mold was not consistent between the 2 years of the study. The cause of greater disease values in 2001 may have been the result of increased inoculum levels or environmental conditions that were more favorable for disease development. Snap beans were grown at the site for three consecutive years. The field was not tilled in the fall after bean harvest in 1999 and 2000, which allowed for continued disease development with a significant production of sclerotia. Additionally, average air temperatures were lower in 2001 than 1999 during bloom stage, and rain fell on $2 \mathrm{~d}$ during the bloom period (Fig. 4). Rainfall likely extended leaf wetness periods, although short periods of irrigation were applied during late afternoon and evening to encourage disease development even during the rainy period. Snap beans also were harvested at a slightly later maturity in 2001 than in 1999, which may have extended the length of time for disease development. 

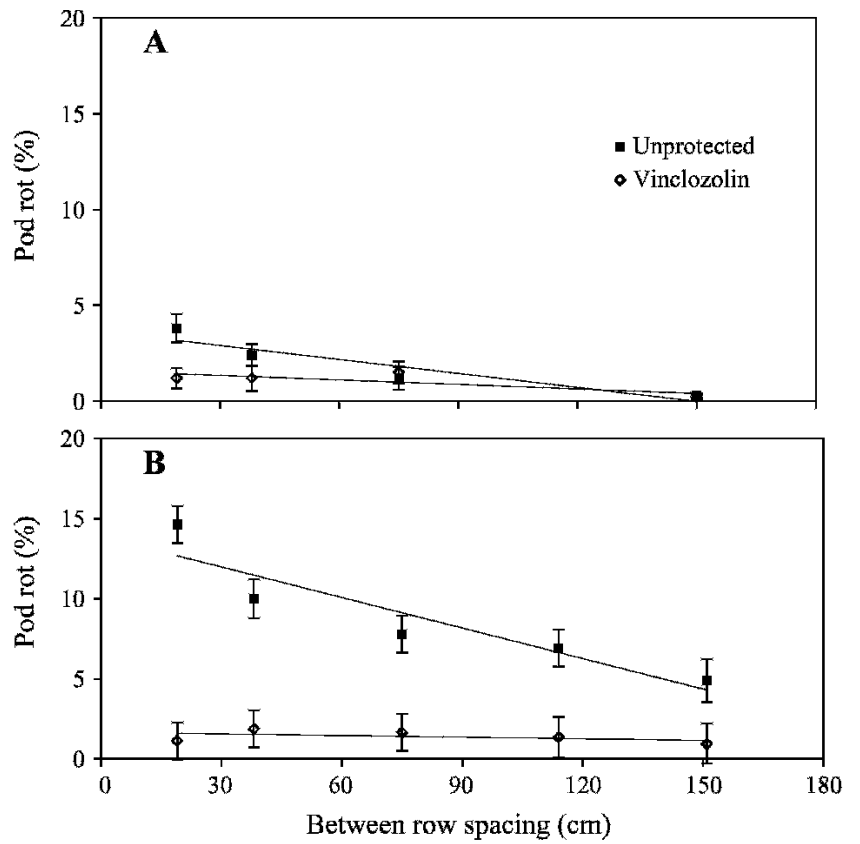

\begin{tabular}{|c|c|c|c|c|c|c|c|c|}
\hline \multirow[t]{2}{*}{ Year } & \multirow[t]{2}{*}{ Fungicide } & \multirow[t]{2}{*}{$\mathrm{F}$} & \multirow[t]{2}{*}{$\operatorname{Pr}>F$} & \multirow[t]{2}{*}{$r^{2}$} & \multicolumn{2}{|r|}{$\alpha$} & \multicolumn{2}{|r|}{$\beta$} \\
\hline & & & & & Par & $\mathrm{CI}_{95}$ & Par & $\mathrm{CI}_{95}$ \\
\hline 1999 & Unprotected & 18.6 & 0.0001 & 0.46 & -0.024 & $-0.036 /-0.012$ & 3.7 & $2.7 / 4.7$ \\
\hline 1999 & Vinclozolin & 1.9 & 0.1802 & 0.08 & -0.007 & $-0.017 / 0.003$ & 1.5 & $0.6 / 2.4$ \\
\hline 2001 & Unprotected & 17.1 & 0.0003 & 0.37 & -0.064 & $-0.096 /-0.032$ & 13.9 & $10.9 / 16.9$ \\
\hline 2001 & Vinclozolin & 0.2 & 0.6613 & 0.01 & -0.002 & $-0.012 / 0.008$ & 1.6 & $0.7 / 2.6$ \\
\hline
\end{tabular}

Fig. 3. Effect of between-row spacing and vinclozolin on incidence of pod rot in snap beans in 1999 (A) and 2001 (B) at a constant planting density ( \pm standard error, $\mathrm{N}=6$ ). Regression statistics and parameter estimates are provided below for the linear models shown in the graphs (pod $\operatorname{rot} \%=\alpha$ $[$ spacing $]+\beta)$

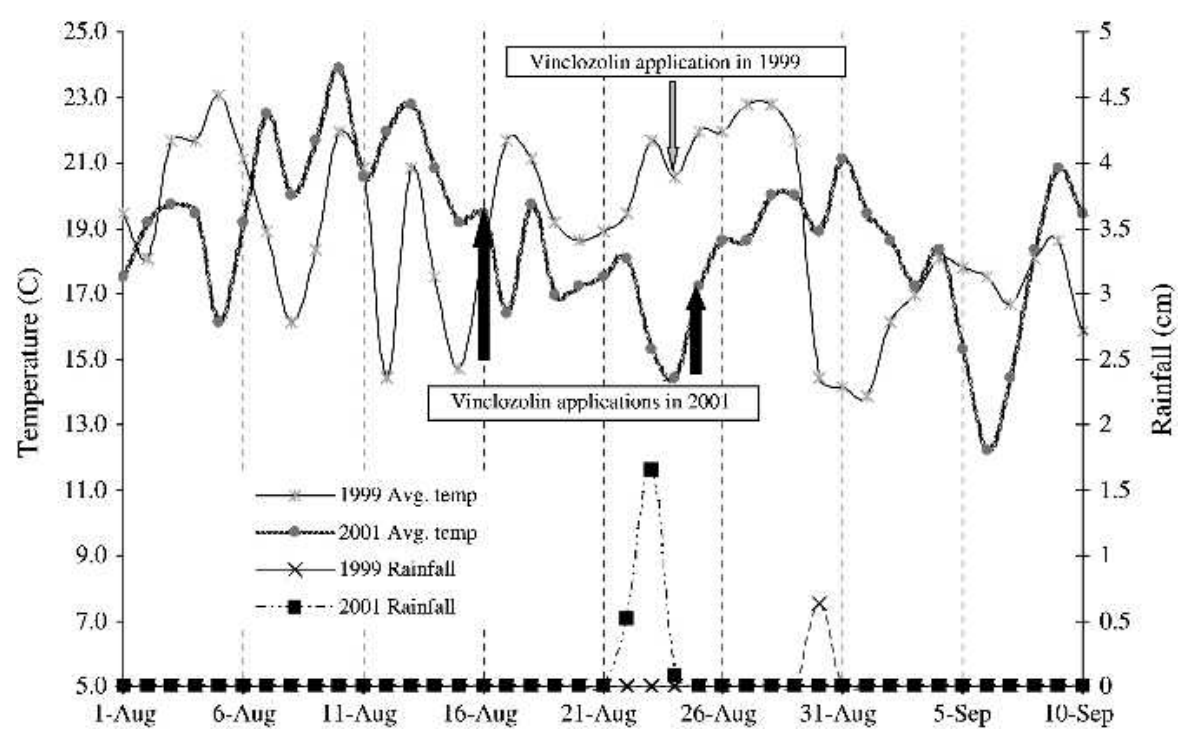

Fig. 4. Average temperature and rainfall and vinclozolin application dates at the Horticulture Farm in Corvallis, Ore., in 1999 and 2001.

Increasing the between-row spacing of crops is often assumed to reduce the risk of white mold. The results of this study support this assumption but do not fully concur with the reports of others. Saindon et al. (1993) reported that plant arrangement and row spacing had no effect on white mold occurrence in both upright and bush type beans; the primary factor was plant architecture. Plants with upright architecture were less likely to develop mold than viney types. White mold was more severe on beans grown on $25-\mathrm{cm}$ than $75-\mathrm{cm}$ between-row spacings; however, between-row spacing was less important for plants with determinate growth habits (Steadman et al., 1973).

In the absence of effective fungicides, widening of the between-row spacing may allow growers to avoid white mold in beans. However, wider between-row spacings may not be sufficient to adequately suppress this disease if environmental conditions are highly conducive for disease development. Although pod rot was reduced by nearly $10 \%$ in 2001 , the disease level at the widest between-row spacing of $150 \mathrm{~cm}$ would still be unacceptable to processors and the yield penalty unacceptable to growers. The results of this study indicate that wider betweenrow spacings may be useful in an integrated mold control program that includes fungicides that are less effective than vinclozolin. If new fungicides with excellent efficacy become available, there may be little incentive to widen the distance between rows. Increasing the distance between snap bean rows had no effect on pod rot in both years when vinclozolin was applied. This may have been the result of better fungicide coverage at the narrower row spacings because of fewer plants per linear unit of row or the exceptional efficacy of vinclozolin in many conditions.

Optimum yields are often equated with higher plant densities and narrow betweenrow spacings, but this hypothesis may only prove true when efficacious fungicides are available to manage white mold. In untreated plots, there was no yield penalty as the between-row distance increased, with the exception of the impractical $150-\mathrm{cm}$ row spacing. In contrast, there was a significant yield penalty associated with increased between-row spacing when vinclozolin was applied. Snap bean yield in 1999 was $27 \%$ greater $\left(5.8 \mathrm{MT} \mathrm{ha}^{-1}\right)$ at the $19-\mathrm{cm}$ betweenrow spacing than the $38-\mathrm{cm}$ spacing. Pod yield was lowest at the widest row spacing $(150 \mathrm{~cm})$ and probably incited by interplant competition (Table 2).

The interaction of row spacing, vinclozolin application, and white mold affirmed our hypothesis that vinclozolin allowed growers to plant snap beans in narrow rows without increasing the risk of white mold. Row spacing had no effect on percent pod rot when vinclozolin was applied. This explains in part the trend toward narrower row spacings over the last two decades. Transitioning to other fungicides that are less effective will require reexamination of the effect of both between-row and within-row plant spacing on white mold development in snap beans and the use of other integrated strategies to suppress the disease. These strategies may include aligning rows with the direction of prevailing winds and shutting off irrigation in the early afternoon to reduce leaf wetness periods. 
Table 2. Effect of between-row spacing and vinclozolin on snap bean plant populations and pod yield. ${ }^{z}$

\begin{tabular}{|c|c|c|c|c|c|c|}
\hline \multirow{4}{*}{$\begin{array}{l}\text { Between-row } \\
\text { spacing } \\
(\mathrm{cm}) \mathrm{m}\end{array}$} & & & \multicolumn{4}{|c|}{ Pod yield } \\
\hline & \multicolumn{2}{|c|}{ Plant density at harvest } & \multicolumn{2}{|c|}{1999} & \multicolumn{2}{|c|}{2001} \\
\hline & 1999 & 2001 & Vinclozolin & Unprotected & Vinclozolin & Unprotected \\
\hline & \multicolumn{2}{|c|}{ Plants ha ${ }^{-1}$} & \multicolumn{4}{|c|}{$\overline{\mathrm{MT}} \mathrm{ha}^{-1}$} \\
\hline 19 & $393,000 \mathrm{a}^{\mathrm{y}}$ & $384,000 \mathrm{a}$ & $27.2 \mathrm{a}^{\mathrm{y}}$ & $20.0 \mathrm{bc}$ & $25.0 \mathrm{ab}^{\mathrm{x}}$ & $20.0 \mathrm{bc}$ \\
\hline 38 & $431,000 \mathrm{a}$ & $416,000 \mathrm{a}$ & $21.4 \mathrm{~b}$ & $18.6 \mathrm{bc}$ & $28.0 \mathrm{a}$ & $20.3 \mathrm{Bc}$ \\
\hline 75 & $380,900 \mathrm{a}$ & $372,000 \mathrm{ab}$ & $19.1 \mathrm{bc}$ & $21.1 \mathrm{~b}$ & $25.0 \mathrm{ab}$ & $24.5 \mathrm{Ab}$ \\
\hline 114 & $-^{x}$ & $388,000 \mathrm{a}$ & - & 一 & $23.7 \mathrm{ab}$ & $21.9 \mathrm{~B}$ \\
\hline 150 & $389,000 \mathrm{a}$ & $309,000 \mathrm{~b}$ & $16.9 \mathrm{bc}$ & $15.1 \mathrm{c}$ & $17.6 \mathrm{c}$ & $16.4 \mathrm{C}$ \\
\hline
\end{tabular}

${ }^{\mathrm{z}}$ Initial planting density was 445,000 plants $\mathrm{ha}^{-1}$.

${ }^{y}$ Means within the same year followed by the same letter do not differ significantly $(\alpha=0.05)$.

${ }^{x}$ Between-row spacing of $144 \mathrm{~cm}$ not included in study in 1999.

\section{Literature Cited}

Abawi, G.S. and R.G. Grogan. 1979. Epidemiology of diseases caused by Sclerotinia species. Phytopathology 69:899-904.

Blad, B.L., J.R. Steadman, and A. Weiss. 1978. Canopy structure and irrigation influence white mold disease and microclimate of dry edible beans. Phytopathology 68:1431-1437.

Defransico J. 2005. Pest management strategic plan for processed snap beans in Oregon and Washington. Oregon State University Extension Service. Available at: http://wsprs.wsu.edu/ SnapBeanPMSP.pdf. Accessed April 11, 2006.

Deshpande, R.Y., K.G. Hubbard, D.P. Coyne, and J.R. Steadman. 1995. Estimating leaf wetness in dry bean canopies as a prerequisite to evaluating white mold disease. Agron. J. 87:613-619.

Grau, C.R. and V.L. Radke. 1984. Effects of cultivars and cultural practices on Sclerotinia stem rot of soybean. Plant Dis. 68:56-58.
Johnson, K.B. and M.L. Powelson. 1983. Fungicide evaluation for control of gray mold and white mold of snap beans. Fung. and Nemat. Tests 38:91-92.

Kerr, E.D., J.A. Smith, C.D. Yonts, and R.G. Wilson. 1992. Fungicide efficacy for bean white mold under different plant populations and row spacings. Ann. Rep. Bean Improv. Coop. 35:52-53.

Ludwig, L.W. and L.B. Hunter. 1990. Efficacy of fungicides applied after inoculation for control of white mold of snap beans. Fung. and Nemat. Tests 45:96.

Ludy, R.L. and M.L. Powelson. 1992. Efficacy of foliar fungicides for control of gray mold and white mold of snap beans. Fung. and Nemat. Tests. 48:100.

Mack, H.J. and G.W. Varseveld. 1982. Response of bush snap beans (Phaseolus vulgaris L.) to irrigation and plant density. J. Amer. Soc. Hort. Sci. 107:286-290.
Mansour, B. and D. Hemphill. 2002. Vegetable Production Guidelines. Horticulture Department, Oregon State University. Available at: http://oregonstate.edu/Dept/NWREC/ vegindex.html. Accessed April 11, 2006.

Park, S.J. 1993. Response of bush and upright plant type selections to white mold and seed yield of common beans grown in various row widths in southern Ontario. Can. J. Plant Sci. 73: $265-272$.

Powelson, M. 1980. Fungicide evaluation for control of gray mold and white mold of snap beans. Fung. and Nemat. Tests. 35:57-58.

Saindon, G., H.C. Huang, G.C. Kozub, H.H. Mundel, and G.A. Kemp. 1993. Incidence of white mold and yield of upright bean grown in different planting patterns. J. Phytopathol. 137:118-124.

Saindon, G., H.C. Huang, and G.C. Zozub. 1995. White-mold avoidance and agronomic attributes of upright common beans grown at multiple planting densities in narrow rows. J. Amer. Soc. Hort. Sci. 120:843-847.

Shah, D.A., H.R. Dillard, and A. Cobb. 2002. Alternatives to vinclozolin (Ronilan) for controlling gray and white mold on snap bean pods in New York. Plant Health Prog. Sept:1-6.

Steadman, J.R., D.P. Coyne, and G.E. Cook. 1973. Reduction of severity of white mold disease on great northern beans by wider row spacing and determinate plant growth habit. Plant Dis. Rep. 5:1070-1071.

Wahab, M.N.J., D.H. Dabbs, and R.J. Baker. 1986. Effects of planting density and design on pod yield of bush snap bean (Phaseolus vulgaris L.). Can. J. Plant Sci. 66:669-675. 